\section{Mães relutantes, avós maternais e pais esquecidos: $o$ fazer e desfazer das relações de parentesco em} Apiao, Chiloé Reticent Mothers, Motherly Grandmothers and Forgotten Fathers: the Making and Unmaking of Kinship in Apiao, Chiloé

\author{
Giovanna Bacchiddu*
}

Resumo: Este artigo ilustra as experiências da maternidade e das relações familiares do povo de Apiao, no sul do Chile. O valor do conceito de maternidade é geralmente diminuído, assim como a noção de vínculo biológico entre mãe e filho. $\mathrm{O}$ foco materno passa da mulher que pariu a criança para a mulher que a cria, um papel frequentemente assumido pelas avós, quem geralmente são chamadas de 'mães'. A relação familiar é encarada como um estado potencial, determinado não só pelos vínculos sanguíneos, mas por ações constantes de amor e carinho. A memória do carinho recebido perpetua as relações e determina os laços de parentesco, por outro lado, a falta de afeto e carinho pode invalidar esses laços. A paternidade depende exclusivamente do reconhecimento público por parte do homem.

Palavras-chave: relações familiares; Chiloé; maternidade.

Abstract: This article illustrates experiences of motherhood and kinship amongst Apiao people, in Southern Chile. Motherhood is generally downplayed, as is the biological tie between mother and child. The maternal focus shifts from the woman who gave birth to the woman who raises the child - a role often taken by grandmothers, who are the ones referred to as 'mothers'. Kinship is experienced as a potential state, determined not by blood relations but by constant acts of loving care. Memory of received care perpetuates relations and determines kinship. Conversely, lack of affection and care may render kin ties invalid. Fatherhood is strictly dependent on a man's public acknowledgement of paternity.

Key words: kinship; Chiloé; motherhood.
* Doutora em Antropologia Social pela Universidade de St. Andrews. É autora de diversos artigos sobre a sociabilidade e a religião em Apiao, Chiloé. Recentemente, realizou um estudo sobre um caso de adoção internacional, com foco na adoção de crianças do sul do Chile por pais italianos. Atualmente, é professora da Pontifícia Universidade Católica do Chile. E-mail: gbacchiddu@uc.cl 
O conceito de 'mãe' não se manifesta meramente nos processos naturais (gravidez, parto, aleitamento e criação dos filhos), mas em uma construção cultural que as diferentes sociedades formam e elaboram, cada uma a sua maneira. Moore (1988, p. 25)

O amor materno é tudo menos natural e, na realidade, representa uma matriz de imagens, significados, sentimentos e práticas produzidas social e culturalmente em todos os lugares. Scheper-Hughes (1992, p. 341)

\section{Introdução: señora o señorita?}

Durante o primeiro período do meu trabalho de campo em Apiao, uma pequena ilha no arquipélago de Chiloé, no sul do Chile, as pessoas me perguntavam direta e indiretamente se eu era "senhora ou senhorita". Quando eu respondia que era senhorita, me perguntavam então se eu tinha filhos. A resposta negativa me classificava imediatamente como uma pessoa estranha ou suspeita: uma mulher jovem, solteira, sem filhos, longe de seu país, de sua casa e seus bens; mal conseguiam me entender. Muitos sugeriam a mesma coisa: que eu me estabilizasse, achasse um marido e construísse um lar. A ideia de me verem casada, uma mãe ocupada com várias crianças, parecia uma obsessão deles naquela época (cf. Rubenstein, 2004; Gow, 1991, p.123). Meus amigos me importunavam ao me oferecerem vários pretendentes e imaginarem minha vida com um homem de Apiao. Os comentários eram feitos sempre de forma bem humorada. "Você tem que se casar logo", me disse uma mulher, "antes que se te enfríe la cacerola" (antes que sua panela esfrie). Essa frase, claramente sarcástica, gerava sempre uma explosão de gargalhadas. $\mathrm{O}$ fato de eu aparentemente me negar a procurar um parceiro e iniciar um relacionamento, indicava que eu estava fora do caminho que uma mulher da minha idade deveria seguir.

Nos termos de Apiao, esse desvio se definia de várias formas: estar solteira, sem filhos e longe de minha família. Não ter um marido ou parceiro era motivo de comentários e julgamentos sobre eu ser uma pessoa difícil ou mimada, insinuando minha rejeição a todos aqueles que me cortejavam. Em Apiao, mulheres solteiras muitas vezes engravidam ao se envolverem com homens, casados ou solteiros. Algumas mulheres decidem deliberadamente ter filhos, correndo o risco de serem mães solteiras, mesmo sabendo que seus parceiros não querem, ou não podem casar com elas. Existem muitas mães solteiras na ilha, mas ninguém na comunidade as culpa ou estigmatiza. Por outro lado, mulheres solteiras sem filhos são consideradas sem sorte e dignas 
de pena, por fazerem todas as tarefas domésticas sozinhas e não terem ninguém que cuide delas durante a velhice. Enfim, há apenas uma boa razão para as pessoas viajarem para longe e se distanciarem de suas famílias: o trabalho. Os chilotes migram para o sul do Chile e da Argentina e mandam dinheiro ou bens para suas casas, porém, no meu caso, eu cheguei de longe para estudar, não para trabalhar, e não estava ganhando, mas gastando dinheiro. Para eles, isso demonstrava uma ausência deliberada da casa dos meus pais, portanto, um sinal de egoísmo.

No presente artigo, tentarei revelar a compreensão das pessoas de Apiao sobre as relações familiares, expondo o contexto etnográfico em que as relações são representadas e ativadas, ou esquecidas e invalidadas. Inspirada no trabalho de Schneider e em recentes estudos das relações familiares dos Ameríndios, os quais enfatizam o papel crítico do agir na determinação dessas relações, pretendo destacar dois traços fundamentais das relações de parentesco em Apiao: sua potencialidade e sua dependência de um código de conduta. As pessoas de Apiao experimentam o parentesco como um valor potencial - algo que está sempre presente, porém de um modo latente - esses laços precisam ser ativados e validados. A validação tem origem em um código de conduta preciso que transforma as pessoas em parentes de fato. Schneider (1984) destaca, em sua crítica aos estudos de parentesco, que as relações entre as pessoas não estão necessariamente baseadas em laços pré-estabelecidos, mas dependem do que as pessoas fazem umas pelas outras. Ele rejeita qualquer definição de família que se concentre no parentesco biológico que, em sua opinião, se baseia em um modelo ocidental e inerentemente etnocêntrico. Alguns grupos, como os Yap, estudados por Schneider, baseiam sua visão do parentesco no fazer e não no ser, em que "somente a constância de ações corretas [...] os mantém afiliados" ao grupo (1984, p.86).

Essa visão encontra eco na comunidade de Apiao. Diferentemente de seus vizinhos Mapuches, os habitantes de Apiao não consideram as relações de parentesco como um aspecto essencial da pessoa. Tampouco existe um significado especial em compartilhar a mesma descendência com outros ${ }^{1}$. Nem o parentesco nem o pertencimento à mesma família possui um significado per se, no entanto traz consigo uma potencialidade implícita de se tornar uma relação social ativa. As pessoas devem desenvolver e negociar as conexões com seus parentes da mesma maneira que o fazem com os que não são membros da família. Uma vez ativada, essa conexão precisa ser mantida

\footnotetext{
${ }^{1}$ Gostaria de destacar a falta de interesse do povo de Apiao pela linhagem e pelo patriarcalismo, em oposição aos seus vizinhos do povo Mapuche. Não é minha intenção representar os Mapuche de maneira simplista e como um povo essencialista. Embora seja necessária uma comparação mais completa entre as duas visões sobre a família, o que será feito em algum momento, as limitações de espaço impedem que estas sejam feitas aqui.
} 
através de presentes, visitas e expressões de afeto. Todos os elos familiares, inclusive entre mãe e filho, precisam ser mantidos vivos através de amor e carinho constantes. A experiência da relação familiar depende daquilo que eu me refiro como 'memória ativa', de acordo com a expressão local "acordarse de uno". Nas palavras de Schneider, se não houver uma ativação através de 'ações corretas', então o parentesco não se desenvolverá.

Essa base das relações familiares no 'fazer' ao invés do 'ser' é vista de maneira muito evidente na maneira como as pessoas de Apiao veem a maternidade. O parto não torna uma mulher mãe, a menos que ela crie seu filho. A mulher que cria a criança é considerada e tratada como a mãe. O laço mais forte é aquele desenvolvido com a mulher que cria, que nem sempre é a mãe biológica. Das duas categorias locais - mulheres que parem e mulheres que criam - a que cria é definida como mamá. É ela quem cria os laços de parentesco.

Tomando como ponto de partida a potencialidade inerente das relações familiares e sua estrita dependência na conduta, este texto explora as atitudes com relação à maternidade, que são geralmente minimizadas em Apiao. $\mathrm{O}$ artigo, portanto, ilustra o modo como avós e netos se relacionam, mostrando que sua relação gira em torno do lar em que habitam. A diferença crucial entre 'parir' e 'criar' destaca o tipo de relações valorizadas e enfatizadas, bem como aqueles que são descartados. A importância que se dá localmente a lembrar e gostar de alguém, é o valor que de fato une as pessoas e forma uma família. O oposto, ou seja, esquecer-se de alguém, é a negação do parentesco e pode apagar os laços familiares. Isso ocorre frequentemente com homens que têm filhos e não se casam com as mães: serão esquecidos para sempre e nunca formarão parte da família da criança.

Meu trabalho ilustra alguns argumentos traçados por Henrietta Moore em sua avaliação das teorias de gênero feministas. Ela sugere que nem sempre são as mães que cuidam dos filhos, que as unidades domésticas não são necessariamente compostas pelas mães e as crianças, e que a maternidade como fato biológico não cria uma unidade ou uma relação universal entre mãe e filho (1988, p.26). O que veremos a seguir destaca a expressão dessa temática no contexto particular de Apiao.

Apiao é parte de uma pequena e desconhecida área do Cone Sul, o arquipélago de Chiloé. É uma ilha de 13 quilômetros quadrados com uma população de aproximadamente 700 pessoas vivendo em casas dispersas pela ilha. O povo de Apiao tira seu sustento da agricultura, pequenas criações de animais, pesca e coleta de frutos do mar e de algas marinhas. Descendentes dos Huilliches, um ramo sulino do grupo mapuche, eles conservam nomes indígenas para pessoas, lugares e alguns termos misturados com o espanhol local. Convertidos ao cristianismo por missionários jesuítas, no século XVII, autodenominam-se Chilotes, (habitantes de Chiloé), ou gente de isla (gente da 
ilha). A sociedade de Apiao é fortemente igualitária, assim como no resto da região de Chiloé. O centro de todas as relações de parentesco em Apiao é o domicílio, onde as famílias moram e trabalham. Estes consistem, em geral, em uma ou mais construções rodeadas por terras e demarcadas por cercas. São residências e ao mesmo tempo unidades produtivas independentes. Nas casas estão os pertences das pessoas, seus animais, assim como sua terra e tudo aquilo que produzem. O cumprimento das tarefas diárias perpetua a existência do lar e da família que vive ali. Morar nesse lar e cultivar suas terras representa a base para a herança patrimonial, a casa e seu terreno pertencem a quem a habita de maneira produtiva. Ao morarem e produzirem nesse espaço, as pessoas ativam e materializam a potencialidade implícita da produção e consequentemente, da vida. Por outro lado, ao abandonarem o lar e suas terras, as pessoas transformam um núcleo potencial de geração de vida em um lugar vazio e infértil, uma ideia que gera tristeza para os habitantes da ilha.

Os casais geralmente passam o período logo após o casamento na casa dos pais de um dos cônjuges, geralmente do homem² ${ }^{2}$. A vida comunitária não implica somente a propriedade coletiva de recursos, terra e animais. Enquanto moram com os donos da casa, o jovem casal cuida e administra seus próprios recursos: um jardim, uma plantação de batata, porcos, galinhas, ovelhas ou vacas. A pós certo tempo, que varia entre alguns meses ou anos, o casal e seus filhos se mudam para uma casa nova e independente. Somente os casados se mudam para um lar independente, aqueles que não se casarem, tanto homens quanto mulheres, permanecem morando com seus pais ou avós. A construção de uma nova casa está intimamente associada ao casamento e à produção agrícola (sobre esse ponto, ver também Gow, 1989). Das cerca de 200 casas existentes na ilha, algumas são formadas por famílias nucleares, e outras, por dois ou mais casais de diferentes gerações, mais os filhos solteiros. Nessas casas, as mulheres, casadas ou não, engravidam e têm bebês.

\section{Y después, me enfermé una vez más! Mães relutantes}

Embora meus anfitriões, e todos os habitantes de Apiao que conheci, se mostrassem preocupados com que eu tivesse filhos, pareciam pouco interessados no conceito de maternidade propriamente dito. Era comum notar uma atitude indiferente com relação à maternidade. Um dos momentos mais evidentes em que a maternidade se via minimizada era a gravidez. As mulheres se referiam à gravidez como enfermedad ou doença ${ }^{3}$. 'Então, eu adoeci de novo' , 'Y después, me enfermé una vez más' me disse uma mulher, lembran-

\footnotetext{
${ }^{2} \mathrm{~A}$ virilocalidade, no entanto, não é prescritiva.

${ }^{3}$ Ver também Platt (2001, p. 642), quando relata que as mulheres andinas usam o termo unqusqa, ou "doente", ao se referirem à gravidez.
}

Tellus, ano 12, n. 23, jul./dez. 2012 
do as várias vezes que engravidou. Uma gestante reduz sua capacidade de trabalho e sua eficiência, como se estivessem doentes. As mulheres grávidas geralmente agem como se não estivessem esperando um bebê, e, muitas vezes, é difícil perceber se estão ou não. Nada em seu comportamento, discurso ou vestimenta revela sua condição, e elas nunca falam sobre o assunto, tanto as solteiras quanto as casadas. Elas continuam a desempenhar tarefas domésticas, mesmo estando grávidas. Uma mulher me contou como estava trabalhando arduamente na plantação de batata quando precisou parar porque o bebê estava prestes a nascer, outra me contou como tinha cozinhado para todo mundo logo após o parto ${ }^{4}$.

Até duas décadas atrás, as mulheres da ilha costumavam dar à luz com a ajuda de parteiras, porém hoje têm acesso a uma equipe de profissionais composta por um médico, uma enfermeira e um obstetra que moram na ilha. $\mathrm{O}$ obstetra aconselha as futuras mães que façam exames regulares e que se dirijam ao hospital local (na cidade mais próxima, a três horas de barco) com bastante antecedência para garantir que as más condições meteorológicas não coloquem em risco a vida delas e da criança. No entanto as mulheres de Apiao se mostram relutantes em deixar seus lares e seus outros filhos e geralmente deixam a viagem para os últimos momentos da gravidez. Uma vez, a equipe médica identificou que uma mulher prestes a parir sofria de uma condição hepática grave. $\mathrm{O}$ obstetra tomou todas as providências para que ela fosse levada ao hospital imediatamente. A mulher começou a chorar, alegando que não podia ir, pois havia muitas coisas para fazer em casa e tinha que alimentar suas sete crianças. Outra mulher que passava por uma gravidez de risco foi aconselhada a repousar, se possível deitada na cama. Meia hora depois a vimos carregando um saco de 40 quilos de trigo sobre os ombros. Ela respondeu à desaprovação do obstetra com um sorriso tímido e seguiu apressada em direção a casa.

Tanto as mulheres casadas quanto as solteiras demonstram uma atitude semelhante com relação à gravidez. Não falam sobre o assunto e agem como se não estivessem esperando um bebê, fazendo as mesmas tarefas diárias que, segundo sua visão, as definem mais do que a maternidade. As pessoas mais próximas das grávidas compartilham essa relutância com relação à gravidez das futuras mães. Consideram os partos como eventos cotidianos que, apesar de bem vindos, não exigem comemorações ou reações emocionais explícitas. Esse afastamento lembra os relatos históricos de Shorter sobre a indiferença à

\footnotetext{
${ }^{4}$ Esta atitude com relação à gravidez certamente não se limita a Apiao (ver, por exemplo, Schepher-Hugues, 1992). Ao mencionar o sul do Chile, Urbina (1983, p. 112) relata que um grupo de indígenas austrais especializados em pesca e mergulho foram levados para Chiloé no final do século XVIII por missionários jesuítas. Mergulhar atrás de frutos do mar era uma tarefa feminina e estar grávida, mesmo em estágios avançados, ou ter acabado de dar à luz, não constituíam nenhum impedimento. Faron (1961, p. 136) escreve sobre os Mapuches e diz que uma mulher prestes a parir "pode continuar ativa até o começo do trabalho de parto".
} 
gestação observada durante a Idade Média até o final do século XIX e começo do século XX. A falta de afeto materno das europeias para com seus bebês, o que Shorter definiu como 'sociedade tradicional' em oposição à 'sociedade moderna', está muito bem documentada em um estudo detalhado sobre a composição da família moderna. "A boa maternidade é uma invenção da modernização" ele afirma (1976, p.168), sem oferecer de fato uma definição de "boa maternidade". Não quero dizer que o afeto materno não existe em Apiao. Minha intenção é analisar as maneiras de experimentar e expressar o amor de mãe que observei. Como mostrarei mais adiante, não falta amor materno em Apiao, mas é possível que ele não venha necessariamente da mãe biológica. Em Apiao, valoriza-se a autonomia pessoal e a capacidade de independência dos indivíduos, é o que realmente define uma pessoa, independentemente do gênero. Ser uma pessoa autônoma e produtiva significa cuidar das plantações de batata, dos animais domésticos, atender os moradores da casa, alimentando-os, servindo bem os convidados, retribuindo os presentes e realizando eventos religiosos quando necessário. Nesse sentido, a sociabilidade se fundamenta no princípio da autonomia pessoal, como o conceito do povo piaroa ilustrado de forma eloquente por Overing (por exemplo, 1989; 1993). A ênfase é posta sempre na produtividade e na capacidade de viver o cotidiano doméstico de maneira ativa, de ativar a potencialidade do lar e da terra. A gravidez, assim como ter filhos, é simplesmente uma fase necessária e normal dentro do ciclo produtivo e não merece qualquer atenção especial.

\section{Avós maternais}

A pouca ênfase dada ao laço entre mãe e filho em Apiao se observa também no uso dos termos usados para definir as relações familiares. As crianças raramente chamam suas mães de 'mãe'. Elas, assim como os adultos de trinta e quarenta anos, se referem a seus pais pelo seu primeiro nome ${ }^{5}$. Por outro lado, as crianças tendem a se dirigir a seus avôs e avós (especialmente as avós) pelo termo, mamá ou mami (usados como sinônimos) e papá. Sempre que se referem a eles em conversas, as pessoas utilizam o vocativo precedido pelo adjetivo possessivo. A mulher que me hospedava dizia às suas crianças que "fossem dormir com sua mamá", se referindo a sua própria avó, uma mulher em seus noventa anos, a quem as crianças também chamavam mamá.

\footnotetext{
${ }^{5}$ Durante um período recente de trabalho de campo (2012) descobri que muitas mulheres por volta dos vinte anos de idade ensinavam seus filhos a se referirem a elas como mamãe (mamás) e a seus pais como avós (abuelos). O fato de que essa tendência recente é relevante e que deverá ser explorada com mais profundidade no futuro, não invalida os dados apresentados aqui, que descrevem a visão sobre as relações familiares em Apiao segundo registros feitos durante um período significativo (2001-2013) e que atualmente se aplica à maioria dos moradores da ilha.
}

Tellus, ano 12, n. 23, jul./dez. 2012 
Certa vez perguntei para a pequena Miria quem tinha trançado seu cabelo. "Mi mamá" respondeu, indicando sua avó. "Mas eu conheço sua mãe, a Ana, onde ela está?" eu disse. A garota respondeu, 'Ah! Você quer dizer minha outra mãe?' Ela depois me explicou que tinha duas mães e dois pais: aqueles com quem ela morava (os avós) e outro casal que morava do outro lado da ilha (seus pais). Em outro caso, uma senhora idosa me contou sobre seus netos com muito orgulho. Mostrou-me a foto da formatura do garoto, e disse "Olha, o papá dele o acompanhou à cerimônia!" apontando para seu marido. Outra mulher, falando sobre sua mãe, comentou: "Nós chamamos ela simplesmente de Tato. Nunca mamá. Somos todos iguais, todos parejos". A bisavó da família que me hospedava certa vez fez um comentário parecido: "Yo nomás soy la mama, ellos son todos hermanos" (Eu sou a única mãe, eles são todos irmãos!) disse ela em tom de brincadeira, comentando sobre o fato de que as crianças chamavam seus pais pelo nome, como se fosse irmãos, e ela era chamada de mamá. Em outra ocasião, após o funeral da tia idosa que o havia criado, um homem com os olhos cheios de lágrimas agradeceu a todos por terem acompanhado "sua mãe" em sua última visita à igreja. Um avô orgulhoso, lembrando o quão próximo era de seu neto bebê, mais próximo que seu próprio filho, o pai da criança, repetia constantemente: "Yo nomás soy su papa!" (Eu é que sou pai dele!) Essa declaração de nenhuma forma implica alguma intimidade entre esse homem e sua nora, que por acaso estava presente quando ele disse isso. A relação entre avós e netos (no caso do homem criado pela tia, ela assume o papel de avó-mãe) era sempre enfatizada e definida pelo uso de termos de parentesco.

Também é comum que os mais idosos solicitem ou que lhes ofereçam um neto ou neta para morar junto e ajudar nas tarefas domésticas, dividindo o espaço, o tempo e compartilhando os eventos cotidianos. Pessoas solitárias são dignas de pena, especialmente os mais velhos. Da mesma forma, as crianças podem ser solitárias, se os pais estiverem muito ocupados para cuidarem bem deles. As crianças se mostram dispostas a morarem com seus avós, e essa convivência desenvolve e reforça os laços de ajuda mútua, amor e cuidado. Amor e carinho são continuamente demonstrados através da oferta e recebimento de comida e da ajuda e companhia diária compartilhadas por adultos e crianças. As crianças recebem comida e cuidado e, em troca, fazem companhia e ajudam ao se tornarem membros ativos do lar. São criadas por seus avós e viverão sempre com eles, e finalmente a casa se tornará sua responsabilidade. Isso inclui até mesmo crianças cujos pais ainda estão vivos, pois o que determina as relações familiares da criança são as pessoas e o lugar onde são criadas. O povo de Apiao está perfeitamente ciente dos laços entre a criança e sua mãe biológica, assim como da diferença entre as mães que 'parem' e as mães que 'criam'. Se parir significa trazer à vida, criar implica não só o cuidado com o desenvolvimento da criança, mas também 
compartilhar tempo, experiência, emoções, tarefas e eventos cotidianos. No fim das contas, são consideradas mães aquelas às quais as pessoas se referem como tal, ou seja, as mães de criação. Criar uma criança é um ato supremo de amor, assim como para o povo piro da região do Baixo Urubamba, descrito por Gow (1991). Em Apiao, da mesma forma que para os Piro, a percepção de família está intimamente ligada à experiência pessoal: a memória do cuidado recebido na infância ativa os laços potenciais da relação familiar ${ }^{6}$.

Esses dados se assemelham a outras etnografias de povos Ameríndios. Ao longo das planícies da América do Sul, observa-se uma ênfase no aspecto relacional dos laços familiares ao invés da transmissão genética de substância. Assim como o corpo é lentamente fabricado e moldado mediante diversos processos ativos, também o são as relações familiares, que precisam ser desenvolvidas e alimentadas. Longe de serem óbvias, são relações in fieri. Dentre muitos autores, Vilaça (2002, p. 349) descreve a concepção nativa dos Wari' sobre a família como 'algo continuamente fabricado'. Viegas (2003) apresenta o caso dos Tupinambá de Olivença, no Brasil, em que as relações familiares requerem constante renovação. Taylor $(2001 ; 1996)$ também destaca que, na Amazônia, a sociabilidade e os laços de família estão ligados à memória. "A relações sociais" ela escreve, "são a condensação e a memória dos estados afetivos construídos através da interação diária, do cuidar, do compartilhar e do trabalhar" (1996, p. 206). Gow (1989; 1991; 1997; s/d) equipara a relação familiar à memória, assim como Viegas (2003). Vilaça descreve a importância do afeto e da memória para a criação de vínculos familiares entre os Wari'. "A constituição da família está fortemente baseada na convivência diária e em demonstrações recíprocas de afeto e carinho" (2005, p. 449). Na Amazônia, os pilares da constituição familiar são a consubstancialidade, adquirida através da convivência, da proximidade física e o cuidado recíproco. O laço familiar, no entanto, pode ser feito ou desfeito dependendo das ações das pessoas.

Devido a que a proximidade física é tão importante quanto à consubstancialidade, os Wari' geralmente consideram todos aqueles que moram juntos ou próximos como familiares consubstanciais. Nesse sentido, as crianças adotadas são vistas como filhos legítimos. Inversamente, os parentes genealógicos com quem se tem pouco contato são frequentemente excluídos da lista de familiares (Vilaça 2005, p. 449).

Voltarei a essa questão mais adiante.

O foco relacional não é exclusividade dos povos das planícies sulamericanas. Weismantel $(1995 ; 1998)$ e Canessa $(1999)$ tratam sobre o aspecto

\footnotetext{
${ }^{6}$ Esta é a maneira que as relações são experimentadas e percebidas em Apiao de acordo com o que observei durante um longo trabalho de campo e não um discurso recorrente sobre a família: as pessoas geralmente não se propõem a fazer comentários moralistas sobre como as relações entre as pessoas deveriam ser.
}

Tellus, ano 12, n. 23, jul./dez. 2012 
processual das relações familiares no altiplano do Equador e da Bolívia, respectivamente, e o trabalho de Carsten (1991; 1995a; 1995b; 1997) ilustra a forte associação entre família, alimentação e personalidade na Malásia.

Em Apiao, a conexão estabelecida mediante o criar parece ter uma implicação mais forte que o parir. A avó, figura da criação, é a única a quem se dirigem como mamá. O resto da família, inclusive os pais, são vistos como 'iguais', todos parejos. As pessoas de Apiao não possuem nenhum vocativo de parentesco para irmãos ${ }^{7}$. Os irmãos se chamam por seus primeiros nomes, o mesmo vale para pais e mães, a quem se dirigem da mesma maneira. $\mathrm{O}$ vocabulário familiar também nivela o status de indivíduos pertencentes a gerações diferentes: são todos iguais, exceto os avós que os criam, redefinidos como pais. Todos os outros termos de parentesco desaparecem e as diferentes gerações se apagam perante o símbolo materno da avó de criação.

\section{Mães ausentes}

Na seção anterior, tratei sobre as crianças que possuem ambos, os pais e os avós. Passarei agora às crianças cujas figuras paternas são uma escolha restrita ou inexistente. A relação de amor e carinho entre as crianças e os avós, refletido no uso dos termos de parentesco, torna-se mais evidente no caso de crianças de mães solteiras, chamadas de hijos huérfanos (filhos órfãos) ${ }^{8}$. Mulheres jovens frequentemente se tornam mães solteiras. Assim como todos os indivíduos que não se casam, estas mães solteiras moram na casa em que cresceram. A partir do momento que o 'filho órfão' nasce, passa a pertencer ao mesmo lar que a mãe. A conexão entre a criança e a casa se torna mais forte que a conexão entre a criança e a mulher que a pariu. A mãe pode se mudar para a cidade a trabalho ou se casar e mudar de casa. Em ambos os casos ela deixa a criança na casa, onde sempre haverá um ou mais adultos para morar com ela e alimentá-la.

A vida em Apiao é considerada ideal: a autonomia, a liberdade e a posse de recursos constituem a qualidade de vida. A terra será sempre produtiva

\footnotetext{
${ }^{7}$ As pessoas de Apiao quase nunca usam termos de parentesco: eles costumam se dirigir e falar sobre todos os seus parentes (irmãos, primos, pais, sogros, tios, tias etc.) assim como seus amigos utilizando seu primeiro nome, exceto pelas palavras mamá ou papá, geralmente usadas para descrever os avós, como disse antes.

8 Às vezes a palavra huacho é usada para descrever os 'órfãos'. Esse termo também se utiliza para pequenos animais que se separaram de seu rebanho. Huacho pode ter uma conotação pejorativa que significa bastardo, porém, pode também ser usado de forma carinhosa para se referir às crianças pequenas (mi huachito). Ver também Alfonso (1993, p.213) e Montecino (1996, p.43). É interessante notar que a denominação hijo huérfano mostra que não ter um pai (ser filho de mãe solteira) e ser um órfão são equivalentes em Apiao. O pai que não age como tal é figurativamente tido como falecido. Isso apoia o argumento sobre o 'esquecimento' em oposição à 'lembrança' como maneira de reconhecimento do laço familiar. Ver abaixo. Agradeço a um revisor anônimo por ter chamado minha atenção para esse ponto.
} 
enquanto cultivada e cuidada, fornecendo a maior parte do que se precisa. Ao ativar a produtividade da terra, as pessoas ativam sua própria vida adulta e, consequentemente, sua sociabilidade, ambos os conceitos são potenciais que precisam ser postos em marcha. Contudo os mais jovens são motivados pelos pais a experimentarem a vida na cidade, pelo menos por algum tempo. As cidades se tornam cada vez mais atraentes como uma possibilidade de ganhar dinheiro e ter acesso à modernidade, experiências fora do alcance dos que moram na ilha. Quando uma mãe solteira, sem perspectiva de se casar com o pai da criança, decide ir embora, muitas vezes aconselhada por seus pais, a existência de um ou mais filhos não interfere seus planos. Crianças órfãs (hijos huérfanos) são algo à parte das vidas das mulheres. Maria, uma mãe adolescente e solteira, foi instruída por seus pais a deixar a ilha para trabalhar e 'conhecer o mundo'. A criança não representou um impedimento, nem para Maria, nem para seus pais. Quando anunciou sua intenção de ir embora, perguntei-lhe se ela gostaria de levar a criança consigo. Ela respondeu convicta que não poderia magoar seus pais e que seria algo terrível de sua parte tirar o bebê deles. Aquela declaração deixou claro que a criança estava no lugar certo, na casa onde ela cresceu, sob o cuidado dos donos do lar, seus pais.

O pequeno Pablo, de onze anos de idade e filho de uma mãe solteira, cresceu na casa de sua avó materna, sob seus cuidados, e mal se lembra de sua mãe. Seu mundo familiar era composto por sua mami, que o alimentava, lhe dava ordens e com quem dividia a cama todas as noites. Um dia ele perguntou a ela: 'Você é minha mãe, não é?' A mulher respondeu 'yo te crié pero no te pari" (eu te criei mas não te pari). A situação e a experiência de Pablo é algo extremamente comum em Apiao. A ligação entre o garoto e sua mãe, que o pariu e foi embora, foi substituída pelo laço com a mulher que agora o criava. Sua avó era quem ele chamava de mami, sua mãe nunca foi mencionada, nem se perguntava sobre ela.

As atitudes das pessoas de Apiao em relação à maternidade entram em confronto com as concepções euro-americanas e chilenas. Nas sociedades ocidentais, os papéis de mulher e mãe frequentemente se sobrepõem. A teoria antropológica manteve por muito tempo o conceito básico de Malinowski sobre a família, presumindo a universalidade da família nuclear como componente essencial da sociedade e tendo como premissa que a oposição hierárquica entre público e doméstico fosse válida para todas as culturas. Alguns desenvolvimentos da ideia de Malinowski sobre a universalidade da família nuclear argumentavam que a unidade básica da sociedade era composta por mãe e filho. Daí se origina a sobreposição das categorias de mulher e mãe, uma crença ainda muito forte nas sociedades euro-americanas. Ao mesmo tempo, observa-se uma tendência a considerar que para uma mulher ser mãe é algo 'natural' e evidente e, por outro lado, classificar as mulheres que não 
se dedicam à maternidade como 'antinaturais' (Moore 1988, p.21, passim. Ver também Schneider, 1984, p.90). O vínculo supostamente natural entre mãe e filho era visto como uma verdade intercultural, a ponto de gerar um debate sobre a questão da 'natureza' versus a 'cultura', nos anos 70. Antropólogas feministas discutiam o fato de que as mulheres são inevitavelmente vinculadas ao âmbito doméstico por causa dos filhos e que o papel pré-definido das mulheres como mães que cuidam e criam limita sua participação em atividades públicas, completamente dominadas por homens. A percepção do papel das mulheres centralizadas no lar e totalmente dedicadas à criação dos filhos é um fenômeno também analisado na literatura latino-americana, sob o nome de marianismo. Esse conceito, discutido, em 1973, por Stevens em um ensaio seminal sobre o tema, conecta as raízes dos estereótipos de gênero ao cristianismo. Stevens destaca como o marianismo (a devoção à imagem sofredora da Virgem Maria) gerou no Chile uma classificação exacerbada das mulheres como mães sofredoras e trabalhadoras, que consideram seus maridos como filhos adicionais. Ela menciona a "santidade da maternidade que cada mulher compartilha com a Virgem Maria" (1973, p.99). De acordo com Stevens, o marianismo está onipresente em todas as classes da sociedade mestiça latino-americana, porém não afeta as populações indígenas (1973, p.91). Da mesma forma, Montecino (1996, p.32) argumenta que o catolicismo deu origem aos dois principais papéis de gêneros no Chile: as mulheres como mães e os homens como filhos. O papel e a imagem do homem como pai é ignorado, enquanto a figura materna é exacerbada. A ausência dos pais fortalece a relação diádica entre mãe e filho.

A forte ênfase no papel materno e a mentalidade do marianismo revelamse no discurso cotidiano das mulheres chilenas, urbanas, das classes média e trabalhadora, como destacam em seus trabalhos tanto Montecino, quanto Stevens. Essas mulheres consideram a maternidade como parte crucial de sua identidade, a ponto de expressarem todas as suas relações (com parentes ou não) usando termos do parentesco e evocando explicitamente esse tipo de relação. Essas mulheres fazem referências constantes a seu papel materno como algo que define sua identidade. Elas costumam representar suas crianças ao se dirigem a elas através dos termos hijo/hija, filho/filha. Frequentemente, também usam essa expressão ao se dirigirem a seus maridos, amigos íntimos e outras crianças, conhecidas ou não, dizendo-lhes mi'jito, mi'jita, ou meu filhinho, minha filhinha. Da mesma forma, os maridos chamam suas esposas de mamá e as mulheres idosas são chamadas de mamita ou mãezinha. E comum escutar mães mencionando o poderoso laço que as conecta aos seus filhos, muito diferente do vínculo entre um homem e uma mulher: o casamento pode acabar a qualquer momento, mas a relação materna não acaba, elas dizem.

O conceito do marianismo e os valores associados a ele, discutidos por Stevens e Montecino, embora relevantes para uma parte da sociedade 
chilena, são generalizações que não se aplicam ao universo social de Apiao. O modelo ilustrado por esses autores se sustenta em traços do cristianismo que não possuem relevância em Apiao, onde não se ouve essa retórica sobre valores maternos, nem sofrimento ou autossacrifício. A ausência do pai (ou mesmo da mãe) não é encarada como abandono e a figura da Virgem Maria, particularmente, não representa um modelo relevante de comportamento feminino. Além disso, os moradores de Apiao são fortemente igualitários: os papéis de gênero são vistos como não hierárquicos, e as tarefas de homens e mulheres são mutuamente divididas. As mulheres de Apiao não se veem primordialmente como mães ou criadoras de crianças. As mães estão longe de serem restringidas ou limitadas pela existência de suas crianças. Para entender esse conceito de maternidade é preciso focalizar-se em certos valores locais: parir versus criar, dois aspectos diferentes da maternidade em Apiao.

\section{Acordarse de uno: lembrar-se do outro}

Em Apiao, as atitudes perante as relações familiares podem ignorar os laços biológicos e substituí-los por laços emocionais. Como disse antes, esse fato tem sido intensamente destacado por Schneider. O povo de Apiao mostrava indiferença com relação às relações incestuosas de longo prazo que existiam na ilha e nunca expressaram algum tipo de juízo de valor sobre isso 9 . Tampouco demonstraram interesse em destacar a conexão entre as crianças e suas mães biológicas, ou seus parentes. No entanto, eles constantemente mencionavam os vínculos emocionais entre parentes e não parentes que se cuidavam e se importavam uns com os outros de maneira prática. Um valor fundamental, que constitui a base de todas as relações significativas, é o que as pessoas expressam como "acordarse de no", literalmente 'se lembrar do outro', pode ser traduzido como ter cuidado ou importar-se com os outros. Os valores associados a esse conceito específico de 'memória' referente às relações familiares possui uma grande semelhança com um termo usado pelo povo piro, descrito por Gow: gishinika, 'pensar sobre, amar, lembrar' (Gow 1991, p. 164; 2000, p. 51, passim). A lembrança é uma ação profundamente valorizada em Apiao, evoca um senso de continuidade emocional articulada mediante gestos de amor e carinho, base para todas as relações significativas. Se expressa através da alimentação, do cuidado, da companhia, da ajuda, das visitas, dos presentes e do contato mantido mesmo à distância. Laços emocionais são criados, ativados e renovados através da lembrança, por outro lado, os vínculos são apagados e esquecidos pela falta de cuidado amoroso.

\footnotetext{
${ }^{9}$ Os casos de incesto ocorriam entre adultos, especificamente relações entre irmãos e irmãs e pais e filhas. Embora os casos fossem excepcionais, a indiferença das pessoas com relação a esse fato é algo significativo e apoia meu argumento.
}

Tellus, ano 12, n. 23, jul./dez. 2012 
Algumas vezes, uma mãe solteira sai de sua casa para se casar. Embora seja mais difícil para uma mãe solteira se casar, não é impossível nem raro que isso aconteça ${ }^{10}$. Nesse caso, os hijos huérfanos são geralmente excluídos da nova família. Não se espera que o marido os receba em seu novo lar e a mulher nunca exigiria a presença de seus primeiros filhos. O novo casal logo mais terá um filho para legitimar sua união e marcar o início de uma nova unidade produtiva. As mães solteiras escolhidas como esposas são consideradas sortudas pela comunidade, as pessoas frequentemente comentam que elas merecem se casar por serem trabalhadoras, habilidosas e boas administradoras do lar. Aqui vemos que, uma vez mais, quando se fala sobre os valores da mulher, a autonomia pessoal é motivo de elogio, e não a maternidade.

Quando Rita, uma mulher de meia idade, começou a se envolver com o homem que se tornaria seu marido, sua filha ainda era uma criança pequena. Ela tentou adiar o casamento porque queria que sua filha crescesse e pudesse se cuidar sozinha. Ela não podia levá-la para sua nova casa, então a deixou morando com sua mãe. Quando a mãe de Rita faleceu um ano mais tarde, as circunstâncias obrigaram a que a menina fosse para a casa do marido de sua mãe. No entanto ela foi bem recebida pela nova família, disse Rita, porque ajudou a criar as crianças. "Esa fué su madre!" (Ela foi uma mãe pra eles!) Trazer uma hija huérfana para a casa do novo casal não era considerado normal, mas o amor e o carinho da garota tornou sua presença aceita e fez dela uma mãe para seus meio-irmãos. Ela se tornou parte de uma família à qual não pertencia graças ao cuidado e o amor demonstrado no novo lar. Por assim dizer, esse amor e carinho que ela deu aos seus meio-irmãos a fez merecedora do termo familiar 'mãe'.

Criar as crianças é um ato supremo de amor e afeto e o primeiro passo para formar um vínculo familiar. As pessoas sempre se lembrarão daqueles que os criam e os considerarão sempre verdadeiros 'pais'. Sempre que se expressa carinho, atenção, companhia e afeto, valores associados à criação, vem logo à tona a noção de lembrança. Acordarse de uno, 'se lembrar', permite que pessoas distantes se aproximem e que pessoas sem vínculos de sangue se tornem 'como familia' ou 'melhor que família', citando um amigo de Apiao (ver também Vilaça, 2002).

Gow (s/d) escreve sobre como os Piro se referem aos laços de família com uma 'linguagem de atenção e consciência': " para que sejam duradouros, os laços de família devem ser mantidos de maneira ativa e intencional durante o dia a dia, ao invés de algo considerado simplesmente uma consequência de eventos passados." Esse mesmo valor de atenção e consciência é expresso

\footnotetext{
${ }^{10}$ Urbina (1983, p. 109) fala sobre um documento de 1788 que conta sobre colonizadores espanhóis de Chiloé que perderam suas noções de honra e vergonha, aceitando se casar com mulheres que não fossem virgens ou que tivessem filhos de relacionamentos anteriores.
} 
em Apiao através da noção de lembrança. Ela permeia as relações entre parentes, assim como as relações sociais em geral. Uma relação de parentesco sem atos de carinho torna os laços de família insignificantes. "Eu tenho dois irmãos", disse uma pessoa da ilha que mora na cidade, "mas só um deles é quem eu amo, ele sempre se lembra de mim; toda vez que vem à cidade, ele me traz alguma, carne, batatas." Uma mulher me contou que sentia saudade de sua filha, que havia ido trabalhar na cidade. "Agora que ela foi embora ela sempre se lembra de mim, me manda caixas de comida, roupas." A distância é de alguma forma aliviada pela ajuda constante que as pessoas dão a seus parentes. Vizinhos carinhosos são sempre lembrados e sua ajuda é sempre reconhecida. Genros carinhosos e generosos são mencionados como "melhores que os filhos de verdade", e as pessoas distantes são continuamente lembradas por seus atos de amor e carinho.

\section{Parente esquecido e parente que esquece}

Da mesma forma que a lembrança torna a relação familiar efetiva ou até mesmo a cria, a ausência, a inatividade e a falta de amor podem apagar as pessoas do grupo familiar. Se de um lado do espectro a ênfase está na 'lembrança', do outro lado ocorre o oposto, a falta de memória, o que chamo de 'esquecimento'. As pessoas que mostram amor e cuidado são sempre lembradas; por outro lado, aqueles que não mostram amor e não cuidam de ninguém, são esquecidos. Quando um membro da família é esquecido, nunca é mencionado ou incluído na enumeração de parentes, é eliminado das lembranças como se já não fizesse parte do grupo familiar. Enquanto o amor e o carinho criam laços e transformam pessoas sem parentesco em família, aqueles que esquecem são por sua vez esquecidos, independentemente da relação que tiverem. A seguir veremos a emblemática estória das primas Sara e Teresa, que compartilharam as mesmas experiências na infância e a mesma mamá.

Sara morava com sua família (marido e filhos) e sua avó idosa. O nome da avó era Maria, mas eles sempre a chamavam de mamá. Sara se referia a ela como mi mamá quando falava com outras pessoas. A casa onde a família de Sara morava havia pertencido ao casal formado por Maria e seu marido. Duas de suas filhas, mães solteiras, tinham ido embora da ilha, a trabalho, deixando para trás as meninas (Sara e Teresa), para que fossem criadas pelos avós e, em troca, lhes fizessem companhia. Morar juntos fortaleceu os laços entre avós e netas em detrimento da relação entre mães e filhas. Sara mal se lembra da mulher que a pariu, que havia se mudado para a Patagônia e nunca mais voltaria. Sara sempre se referia à sua avó como mamá. 'Yo me crié con ella' (Eu me criei com ela), declarou quando a visitei pela primeira vez. Depois de se casar, seu marido se mudou com eles porque não tinha 
condições de oferecer uma boa casa e porque a velha mamá precisava que alguém morasse com ela.

A prima de Sara, Teresa, teve uma experiência diferente com sua mãe biológica, a quem conheceu quando tinha quinze anos. Disseram para ela que trocasse de roupa e que se preparasse para conhecer 'sua mãe', que vinha de fora da ilha, havia se casado e agora tinha outros filhos. Ela se lembra de que não queria conhecer aquela completa estranha: "Minha mãe estava ali comigo, eu não precisava de outra mãe." Alguns anos mais tarde, Teresa foi embora da ilha e hoje mora na cidade com sua própria família. Passaram-se trinta anos desde que ela foi embora, mesmo assim ela liga regularmente, visita sua mamá todos os anos e sempre leva ou manda presentes, tais como comida, dinheiro e bens materiais. Como a própria Teresa diz, "eu sempre me lembrarei da minha mamá".

A mãe biológica de Teresa também mora na cidade. Elas não se importam muito uma com a outra, raramente se visitam ou ligam. "Ela é como qualquer outra pessoa pra mim", disse Teresa. "Minha única mãe é minha mamá, a mulher que me criou. Ela me deu tudo, me alimentou e cuidou de mim. Essa mulher não é nada pra mim, não tenho nenhum afeto por ela." $\mathrm{O}$ caso de Teresa exemplifica uma situação comum em Apiao. Embora as pessoas estejam cientes dos laços naturais entre mãe e filho, esse laço pode se tornar irrelevante e insignificante se não vier acompanhado de carinho, companhia e o compartilhamento de comida e tempo. Filhos de mães solteiras geralmente não culpam suas mães por tê-los deixado com seus avós para que os criassem. Apenas se referem ao fato de que o laço biológico nunca se desenvolveu para tornar-se uma relação familiar. No entanto, crianças como Teresa, que foi embora da ilha muito jovem para morar na cidade, demonstram angústia e raiva por terem 'sido abandonadas' por suas mães. Devido à grande ênfase que se dá à relação entre mãe e filho na maior parte da sociedade chilena, não é de surpreender que Teresa, parte dessa sociedade há mais de trinta anos, tenha adotado esse discurso que nada tem a ver com Apiao.

As mães - na verdade, qualquer parente - que não mostram amor e carinho são consequentemente esquecidas. Isso não implica nenhum tipo de culpa ou ressentimento, trata-se simplesmente de esquecimento. Aqueles que não se lembram são apagados da memória das pessoas e jamais são mencionados. Durante alguns meses, eu morei com uma mulher que nunca mencionou seu marido, que havia ido embora, ou seu filho mais velho. Eles foram embora a trabalho e nunca mantiveram contato. Outra mulher idosa uma vez mencionou brevemente que, além dos que eu já conhecia, ela tinha mais dois filhos que moravam no exterior e que tinham se esquecido dela. Nunca tinham escrito ou voltado para vê-la. Quando retornei a Apiao, menos de um ano após os dois anos de trabalho de campo, a bisavó de minha família 
adotiva me recebeu com uma demonstração comovente e emotiva de gratidão. Ela se levantou chorando alto, me chamou de "minha filhinha" e declarou com a voz emocionada seu agradecimento por eu ter "me lembrado dela" visitando-a. Meu retorno tinha que ser celebrado com um choro ritualístico.

Antes de se casar, Sara teve três crianças como mãe solteira. De todas elas, eu conheci uma, que morava em Apiao. Uma delas nunca foi mencionada, e a outra, Juana, apenas uma vez, quando me disseram que morava no exterior. Algum tempo depois, contaram-me emocionados que Juana tinha vindo da Argentina para visitá-la. Tendo esquecido sua mãe por um longo tempo, Juana por sua vez foi esquecida e raramente mencionada. Ao retornar em visita, ela demonstrou amor e carinho, restabelecendo o laço familiar. Bodenhorn (2000) descreve uma característica semelhante entre os Iñupiat do Alaska, para quem as relações familiares são potenciais e podem ser facilmente negociadas. Agir como um parente torna a pessoa um parente de fato. "Se a ação cessa, a relação também se detém. Era comum ouvir alguém comentar `Ele costumava ser meu primo'" (2000, p.136). Apesar de compartilhar essa noção com os Iñupiat, as pessoas de Apiao, pelo contrário, evitam falar daqueles que se esqueceram delas. Parentes que não renovam os laços de amor são excluídos da memória coletiva da família, apagados do grupo familiar. Ao se esquecerem, o laço familiar é desfeito ou desativado. Edwards e Strathern (2000) relatam dados análogos em seu trabalho sobre o pertencimento nas experiências familiares inglesas. A biologia não é suficiente para manter uma conexão: laços não ativados terminam se rompendo. $\mathrm{O}$ esquecimento e a falta de atenção causam a diluição e o desaparecimento dos relacionamentos nos casos específicos descritos pelo autor. Em Apiao, isso pode acontecer com filhos, mães e, de forma mais dramática, com os pais de hijos huérfanos: os parentes mais esquecidos.

\section{Relação 'interrompida'}

Sempre que uma mãe solteira engravida, ela sabe que, a menos que seu parceiro queira se casar, a responsabilidade pela criança será totalmente dela. Ela será a única referência, e sua família vai ser a única família da criança. No Chile, assim como em todos os países hispânicos, as crianças recebem tanto o sobrenome paterno quanto o materno. Filhos de mães solteiras invariavelmente herdam o sobrenome da mãe duas vezes, ou seja, o sobrenome da mãe substitui o do pai ausente. Em Apiao, a afiliação do recém-nascido à família paterna depende inteiramente do reconhecimento público da paternidade por parte do homem. Isso normalmente significa morar juntos ou se casarem (o casamento sendo sempre posterior a morar juntos). A partir do momento que a mulher dá à luz, o homem se depara com a escolha de se casar ou ser completamente excluído da vida dela e da criança. Se ele não se casar com ela, 
isso significa o fim da chance de ter qualquer tipo de relação com a criança, para sempre. Nunca pedirão nada a ele, como dinheiro ou bens para a criança e, provavelmente, ele nunca mais falará com a mãe novamente. Tampouco haverá nenhuma relação entre as respectivas famílias. A existência do homem e seu nome nunca serão mencionados, e a criança não será informada sobre a identidade de seu pai. O duplo sobrenome materno a vincula exclusivamente ao lado materno de sua família.

A ambivalência torna-se uma característica do relacionamento que gerou essa criança: por um lado, um silêncio que a relega a um status de tabu e, por outro, uma reminiscência sempre presente. Esse tratamento duplo do mesmo sujeito é observado principalmente em dois grupos de pessoas: aqueles imediatamente envolvidos (o casal e suas famílias) e a comunidade. Aqueles envolvidos pessoalmente ativam um tipo de memória seletiva e nunca mencionam nada sobre a relação e o parceiro anterior, sendo ambos enterrados no passado. As relações interrompidas são a negação do valor crucial da lembrança. Um homem que nunca consagrou um relacionamento, fez o oposto de se lembrar e cuidar: ele esqueceu. Além do mais, há uma segunda negação, a da produtividade. Esse homem se negou a formar uma unidade produtiva e ativar os laços familiares que ele iniciou, mas acabou deixando-os suspensos, latentes e, finalmente, interrompidos. O efeito colateral é a lembrança dessa interrupção por parte da comunidade. Sempre me diziam quem eram as diversas crianças de mães solteiras, assim como a identidade de seus pais e às vezes, as razões pelas quais o casal nunca formou uma família. Todos sabem e tornam evidente a conexão entre os hijos huérfanos e seus pais ${ }^{11}$. Contudo uma mulher nunca menciona o amante que a largou sozinha com uma criança. $\mathrm{Da}$ mesma forma, um homem que engravidou uma mulher e não se casou com ela nunca menciona sua paternidade. O que acontece entre um homem e uma mulher deve ser oficializado logo após o acontecido ou esquecido para sempre.

As mães solteiras são raramente consideradas culpadas. As pessoas normalmente dizem que elas foram enganadas, las engañaron. Os homens enganam as mulheres, ao fazer-lhes acreditar que eles se importam com elas, só para esquecê-las depois. É doloroso e humilhante para uma mulher admitir que foi enganada por seu amante. Significa reconhecer que ela permitiu que ele se aproveitasse dela ao aceitar ter sexo com ele, mas sem conseguir mantê-lo como marido. Isso não tem relação com algum tipo de moralidade ou religião. Na realidade, as mães solteiras não são estigmatizadas por terem tido sexo antes do casamento, nem condenadas por não terem seguido os dogmas católicos. A pureza e a virgindade não são valores importantes, apesar

\footnotetext{
${ }^{11}$ Isso não significa necessariamente que as pessoas conversem sobre o assunto. Todos estão cientes sobre a identidade do pai da criança da mãe solteira, mas isso não é um assunto para discussão em Apiao.
} 
de a comunidade se declarar fervorosamente católica e ter canções e orações em homenagem à Virgem Maria em seu repertório religioso ${ }^{12}$. A questão do tabu sobre a relação familiar interrompida se relaciona com a objeção ao valor fundamental da lembrança, expressa na forma de negação e rejeição, e não com o pecado, a vergonha ou a desonra. Homens que não se casam com as mães de seus filhos e, portanto, não assumem a paternidade socialmente, não podem reivindicar nenhum direito sobre as crianças, e isso é um dilema do qual não podem escapar ${ }^{13}$. Os laços são completamente rompidos e nunca serão restabelecidos, não só na relação entre homem e mulher, mas também entre pai e filho, uma relação que se torna inexistente. Eu nunca vi uma criança que perguntasse sobre a identidade de seu pai ou sobre a história de vida de sua mãe. "Yo también fui hija huérfana" (Eu também fui filha de mãe solteira), contou-me certa vez a bisavó da casa onde eu morava. "Sara foi uma criança órfã, eu fui uma criança órfã e agora a Maria teve outra criança órfã." Ao enumerar a sequência de crianças criadas sem o pai, ela se incluiu, dizendo que nunca soube quem foi seu pai. $\mathrm{O}$ fato de que as crianças sejam vistas como pertencentes ao lar onde se criam e que sua descendência patriarcal não tenha significado algum (a menos que a criança seja criada por ambos os pais), é particularmente chocante se analisarmos a importância que seus vizinhos do povo mapuche dão aos pais e à linhagem paterna (Course, 2011).

\section{Relações familiares suspensas}

O episódio a seguir ilustra toda essa temática e aquilo a que me refiro como suspensão das relações familiares, ou seja, quando uma mulher está esperando a decisão do homem de lembrar ou esquecer. Uma vez fui junto com Sara levar uma mensagem ao vizinho, Don Francisco. Passamos a tarde em sua casa, conversando sobre a notícia mais recente: na noite anterior um jovem embriagado tinha quase se afogado no canal. Don Francisco, ao escutar os gritos, tinha corrido e salvado o homem. Conversamos sobre o episódio durante um bom tempo. Enquanto falávamos e bebíamos mate, um bebê recém-nascido estava deitado ao lado do fogão. Era a primeira neta de Don Francisco, filha de Laura, sua filha adolescente e mãe solteira. Durante toda a visita, o bebê permaneceu ao lado do fogão, ninguém a apresentou e nenhuma palavra foi dita sobre ela. Pouco antes de irmos embora, Sara sorriu pra ela e o máximo que fez foi perguntar seu nome, e fomos embora. Mais tarde, ela me revelou a identidade do pai do bebê. "Quem sabe eles se casam, quem sabe."

\footnotetext{
${ }^{12}$ Sobre a visão do povo de Apiao sobre o cristianismo, ver Bacchiddu (2009; 2011 e 2012).

${ }^{13}$ As crianças são um recurso valioso como membros de uma casa ou unidade produtiva, tanto em termos emocionais quanto materiais. Um pai que nega a paternidade não poderá jamais receber afeto ou ajuda de seus filhos, caso necessário.
}

Tellus, ano 12, n. 23, jul./dez. 2012 
Vemos novamente a pouca ênfase dada ao nascimento de uma criança. Don Francisco e sua esposa tinham se tornado avós, Laura havia se tornado mãe, um bebê havia nascido. A relação dos amantes não era oficial, o homem não tinha levado a garota para morar com ele. A criança era publicamente reconhecida como filha daquele homem, mas isso não mudou o caráter da relação entre as pessoas envolvidas. $O$ fato de que a mulher e sua filha moravam na casa de seus pais era sinal do desinteresse do homem ou, na melhor hipótese, da sua indecisão temporária. De acordo com a perspectiva das pessoas em Apiao, a relação familiar entre o homem, a mulher e a criança estava latente, permanecendo suspensa até o homem decidir se vai assumir a paternidade socialmente. Se ele não mostrasse intenção de formar uma família, seu laço com a mulher e a criança seria desfeito. Laura e seu bebê estavam em uma posição de relações suspensas. Ninguém sabia o que o pai da criança queria, se proceder ao casamento ou manter o silêncio e continuar com sua vida de solteiro, rejeitando para sempre aquela possível conexão. Casonãooptepelo casamento, esses laços familiares serão interrompidos. Não haverá jamais um reconhecimento da relação de paternidade entre o homem e a criança. A criança não terá direito ao patrimônio de seu pai e nunca será incluída na linhagem daquele homem. Seu sobrenome (o mesmo da mãe, repetido duas vezes) será a marca de uma relação esquecida. Conclusão

Ao analisar os dados de diversas etnografias sobre os Ameríndios quanto à construção das relações familiares, Aparecida Vilaça (2002, p.352) escreve:

Para muitos grupos de Ameríndios, o corpo é um produto de ações sociais particulares que o transformam continuamente. Isso implica uma diferença radical de abordagem: em contraste com nossas próprias ideias, formadas [...] por uma concepção genética da família em que a substância determina as relações sociais, na Amazônia, as relações sociais determinam a substância (Viveiros de Castro 2000, p.29 n. 40, 30).

As relações familiares em Apiao são vivenciadas como um estado passivo e genérico que contém um grande potencial, mas requer intervenção ativa e uma ação sincronizada para tornar-se significativa. Da mesma forma que a terra potencialmente produtiva, mas que requer cultivo para gerar frutos, as relações familiares pedem ações para se tornarem efetivas e frutíferas. Sem trabalho, a terra é apenas um território abandonado e infértil. Sem intervenção ativa, os familiares são vistos como 'outros' genéricos e, portanto, sem nenhum valor especial. Neste artigo, analisei a maneira como as pessoas de Apiao entendem o conceito de parentesco. A família não é entendida como algo pronto, e os laços familiares não são vistos como fixos e determinados pela biologia. Ao invés disso, o povo de Apiao percebe as relações de família como algo potencial. Para se tornarem efetivas, as conexões devem ser constantemente reiteradas, regularmente trazidas à tona através de atos que indiquem uma memória ativa. Lembrar os entes queridos se traduz em 
ações práticas de carinho: fazer companhia, ajudar, dar presentes e, no caso de relações à distância, manter o contato e visitar. Ser um parente per se traz consigo muito potencial, mas permanece um estado genérico que depende da ativação, pois as relações devem ser testadas, mediadas e construídas ao longo da vida. Os laços sanguíneos não aproximam as pessoas, nem tornam as relações privilegiadas. As relações de família são constantemente feitas ou desfeitas de acordo com a forma como as pessoas se tratam.

Há um aspecto público e visível dessa memória ativa: as pessoas que se importam com as outras, e se lembram dos outros, são publicamente visíveis e reconhecidas. Durante as férias de verão e inverno, entre os viajantes frequentes das embarcações, estão alguns nativos da ilha que moram a centenas de quilômetros de distância e que voltam para visitar seus entes queridos, trazem presentes e mostram as diferenças que adquiriram na maneira de se vestir e no sotaque. Sua presença é uma demonstração pública de memória afetiva: eles fazem viagens longas e caras para visitar aqueles que amam, e sua presença no barco é comentada e discutida por todos aqueles que os veem. Da mesma forma, homens que assumem sua paternidade socialmente e formam uma família, demonstram seu status publicamente durante as festividades, ao caminharem em direção à igreja junto com sua esposa e crianças, ao contrário das mães solteiras, que caminham sós com os filhos. Em todas essas situações, existe uma definição e redefinição social daqueles que declaram seu amor e carinho por outras pessoas.

A lembrança é uma ferramenta poderosa para a criação ou o esquecimento dos laços familiares. A expressão 'se lembrar' redefine os laços entre as pessoas, que são acolhidas pelo grupo familiar em um movimento centrípeto, ou excluídas por um movimento centrífugo. Os avós se tornam pais, as irmãs se tornam mães, os genros se tornam filhos, as noras viram irmãs. Por outro lado, as mães se tornam uma pessoa qualquer, os irmãos, filhos e pais se tornam ninguém. A negação máxima da relação familiar é a negação da memória, o desaparecimento da pessoa ausente através do esquecimento constante.

Voltando ao episódio do início deste artigo, em que meus anfitriões sugeriam, não apenas, que me tornasse mãe, mas que iniciasse um relacionamento que me fizesse participar ativamente do mundo: ser autônoma, morar em minha própria casa, tornar a terra produtiva, ter filhos e depois netos. $\mathrm{O}$ que define uma mulher não é parir crianças, mas ser uma pessoa trabalhadora, habilidosa e responsável, os filhos são parte do contexto geral. Uma mulher é livre para construir sua independência e deixar seus filhos para trás, e isso não é visto como algo imoral ou desnaturado. Na realidade, não se diminui o valor da maternidade em si, mas do vínculo entre uma mãe e sua criança. Enquanto houver alguém para alimentar, acompanhar e cuidar da criança, a presença de outra mulher se faz desnecessária. A seguinte frase, frequentemente ouvida, ilustra bem esse conceito: "minha mãe não é a mulher que me 
pariu, e sim a que me criou." Na criação de uma criança, residem os valores que expressam as relações familiares em seu pleno potencial. Uma pessoa que ama e cuida é aquela que se lembra e, em retribuição, será sempre lembrada. Uma pessoa ausente, que se esqueceu, será por sua vez esquecida. Um parente ausente, mesmo consanguíneo, será relegado à condição de um 'outro' sem nenhum destaque ou identificação. Ser mãe não é tão crucial quanto ser um membro ativo do lar, da unidade produtiva onde a vida cotidiana acontece. A paternidade por sua vez é negada a menos que o homem assuma sua criança através do casamento. O carinho, a companhia, a ajuda e a generosidade são a verdadeira substância das relações familiares do povo de Apiao.

$* * *$

Agradecimentos: Esse artigo é dedicado à memória da bisavó Catalina Colin Colin, la mami.

Gostaria de agradecer e reconhecer a Regione Autonoma della Sardegna, na Italia, assim como o Centro Interdisciplinar de Estudos Interculturais e Indígenas - ICIIS - da PUC Chile (GRANT: CONICYT/FONDAP/15110006) por colaborarem com parte do financiamento da pesquisa de campo conduzida durante aproximadamente dois anos, entre 2001 e 2002, e diversas visitas posteriores durante mais de uma década. Agradeço a Peter Gow, Jeanette Edwards, Elizabeth Ewart, Magnus Course, Margherita Margiotti, Veronika Groke, Christos Lynteris e Piergiorgio Di Giminiani pelos comentários feitos sobre as primeiras versões deste artigo, assim como os participantes dos seminários nos Departamentos de Antropologia do LSE (Latin American Seminar) e à Universidade de St Andrews (Departmental Seminar). Agradeço também aos dois revisores anônimos deste trabalho e à Nádia Heusi por seus comentários tão enriquecedores. Muito obrigada a Joseph Tendler por sua assistência durante a fase de revisão e edição do artigo. Finalmente, esta pesquisa não teria sido possível sem a generosidade e a paciência de meus amigos de Apiao, que me acolheram em suas vidas.

\section{Referências}

ALFONSO, Priscilla Delano. Women and work in Chile: the fish-processing industry on the island of Chiloé. Phd Thesis. University of Cambridge, Cambridge, 1993.

BACCHIDDU, Giovanna. 'Before We Were All Catholics': Changing Religion in Apiao, Southern Chile. In: WRIGHT, Robin; VILAÇA, Aparecida (eds.) Native Christians: Modes and Effects of Christianity among Indigenous Peoples of the Americas. Farnham and Burlington: Ashgate, 2009. 
Holding the Saint in One's Arms. Miracles and Exchange in Apiao, Southern Chile. In: FEDELE, Anna; BLANES, Ruy (eds.) Encounters of Body and Soul in Contemporary Religious Practices. Anthropological Reflections. New York and Oxford: Berghahn, 2011.

. 'Doing Things Properly': Religious Aspects in Everyday Sociality in Apiao, Chiloé. In: DEBEVEC, Liza; SKIELKE, Samuli (eds.) Ordinary Lives and Grand Schemes: An Anthropology of Everyday Religion. New York and Oxford: Berghahn, 2012.

BODENHORN, Barbara. 'He used to be my relative': exploring the basis of relatedness among Iñupiat of northern Alaska. In: CARSTEN, Janet (ed.). Cultures of relatedness: new approaches to the study of kinship. Cambridge: Cambridge University Press, 2000.

CANESSA, Andrew. Making persons, marking difference. Procreation beliefs in Highland Bolivia. In: LOIZOS, Peter; HEADY, Patrick (eds.). Conceiving persons: ethnographies of procreation, substance and personhood London: Athlone Press, 1999.

CARSTEN, Janet. Children in between: fostering and the process of kinship on Pulau Langwaki, Malaysia. Man, v. 26, p. 425-443, 1991.

. The substance of kinship and the heat of the hearth: feeding, personhood, and relatedness among Malays in Pulau Langwaki. American Ethnologist, v. 22, n. 2, p. 223-241, 1995a.

The politics of forgetting: migration, kinship and memory on the periphery of the Southeast Asian state. Journal of the Royal Anthropological Institute, v. 1, p. 317$335,1995 b$.

The heat of the hearth: the process of kinship in a Malay fishing community. Oxford: Clarendon Press, 1997.

COURSE, Magnus. Becoming Mapuche. Person and Ritual in Indigenous Chile. Urbana, Chicago and Springfield: University of Illinois Press, 2011.

EDWARDS, Jeanette; STRATHERN, Marilyn. Including our own. In: CARSTEN, Janet (ed.). Cultures of relatedness: new approaches to the study of kinship Cambridge: Cambridge University Press, 2000.

FARON, Luis C. Mapuche Social Structure. Urbana: The University of Illinois Press, 1961.

GOW, Peter. The perverse child: desire in a native Amazonian subsistence economy. Man, v. 24, n. 4, p. 567-582, 1989.

Press, 1991.

Ofmixed blood. Kinship and history in Peruvian Amazonia. Oxford: Clarendon 39-65, 1997.

Parentesco como consciência humana: o caso dos Piro. Mana, v. 3, n. 2, p.

Helpless - the affective preconditions of Piro social life. In: OVERING, Joanna; PASSES, Alan (eds.). The anthropology of love and anger: the aesthetics of conviviality in Native Amazonia. London: Routledge, 2000.

Race and gender in Eastern Peru: two views on a class system. Disponível em: <http:/ / www.desafio.ufba.br/gt1-004.html>. Acesso em: 7 maio 2013.

Tellus, ano 12, n. 23, jul./dez. 2012 
MONTECINO, Sonia. Madres y Huachos. Alegorías del mestizaje chileno. Santiago de Chile: Editorial Sudamericana, 1996.

MOORE, Henrietta L. Feminism and anthropology. Cambridge: Polity, 1988.

OVERING, Joanna. Personal autonomy and the domestication of the self in Piaroa society. In: JAHODA, Gustav; LEWIS Ioan M. (eds.). Acquiring culture. Cross cultural studies in child development. London: Croom Helm, 1988.

. The anarchy and collectivism of the 'primitive other'. In: HANN, Chris M. (ed.). Socialism: ideals, ideologies, and local practice. Oxon: Routledge, 1993.

PLATT, Tristan. El feto agresivo: parto, formación de la persona y mito-historia en los Andes. Anuario de Estudios Americanos, 58, n. 2, p. 633-678, 2001.

RUBENSTEIN, Steven L. Fieldwork and the Erotic Economy on the Colonial Frontier. Signs: Journal of Women in Culture and Society, v. 29, n. 4, p. 1041-1071, 2004.

SCHEPER-HUGHES, Nancy. Death without weeping: the violence of everyday life in Brazil. Berkeley: University of California Press, 1992.

SHORTER, Edward. The making of the modern family. London: Collins, 1976.

STEVENS, Evelyn P. Marianismo: The Other Face of Machismo in Latin America. In: PESCATELLO, Ann (ed.). Female and Male in Latin America. Pittsburgh: University of Pittsburgh Press, 1973.

TAYLOR, Anne Christine The soul's body and its states: an Amazonian perspective on the nature of being human. Journal of the Royal Anthropological Institute, v. 2, n. 2, p. 201-215, 1996.

. Wives, pets and affines: marriage among the Jivaro. In: RIVAL, Laura M.; WHITEHEAD, Neil L. (eds.). Beyond the visible and the material. The Amerindianization of society in the work of Peter Rivière. Oxford: Oxford University Press, 2001.

URBINA, Rodolfo. La periferia meridional indiana: Chiloé en el siglo XVIII. Valparaiso: Ediciones Universitarias de Valparaiso, 1983.

VIEGAS, Susana. Eating with your favourite mother: time and sociality in a Brazilian Amerindian community. Journal of the Royal Anthropological Institute, v. 9, n. 1, p. 31-37, 2003.

VILAÇA, Aparecida. Making kin out of others in Amazonia. Journal of the Royal Anthropological Institute, v. 8, n. 2, p. 347-365, 2002.

. Chronically unstable bodies: reflections on Amazonian corporalities. Journal of the Royal Anthropological Institute, v. 11, n. 3, p. 445-464, 2005.

WEISMANTEL, Mary. Making kin: kinship theory and Zumbagua adoption. American Ethnologist, v. 22, n. 4, p. 685-706, 1995.

. Food, gender, and poverty in the Ecuadorian Andes. Philadelphia: University of Pennsylvania Press, 1988.

Recebido em 16 de abril de 2012

Aprovado para publicação em 17 de julho de 2012 